\title{
Welcome to NorDiNa 2/2013
}

Welcome to the second issue of NorDiNa this year. NorDiNa is now exclusively published online.

The Department of Science and Mathematics Education (MND) at Stockholm University is now part of the academic collaboration to make NorDiNa published. Carl-Johan Rundgren from this department has now joined the editorial team as one of two main editors together with Are Turmo from the Norwegian Centre for Science Education, University of Oslo, Norway. During 2013 Christina Ottander will still continue to be part of the editorial team.

To further strengthen the journal as a true Nordic collaboration, we have now invited and appointed three national co-editors. We are pleased to announce that Kalle Juuti (Finland), Marianne Achiam (Denmark) and Allyson Macdonald (Iceland) all have accepted the invitations to act in this role. The national co-editors will be the main editors' principal contact in their own country. Among their tasks will be to actively promote NorDiNa nationally at relevant conferences, in national journals etc. and to contribute in discussions about the quality and strategic development of the journal. Our vision is to be a leading journal in Europe for Science Education!

We are pleased to see that our Online Journal System is now in full operation. New submissions come in to NorDiNa through this system on a regular basis. Almost 100 users are now registered on the web platform as authors and reviewers. We encourage researchers in science and technology education to create accounts on https://www.journals.uio.no/index.php/nordina/user/register.

This year, one of the initiators of NorDiNa, Björn Andersson at Göteborg University, has passed away. Björn was the first person to write a dissertation on science education in the Nordic countries back in 1976. Björn has made a lasting contribution to the field of science education, not only in the Nordic countries, but also internationally. In this issue, Svein Sjøberg writes a commemorative article on Björn's contribution which is also an exposé of the early days of science education research in the Nordic countries.

Steffen Elmose and Martin Krabbe Sillasen contribute with a text entitled "Naturfaglig kompetence og IBSE". The aim of their article is to generate a theoretical and methodological foundation to be able to evaluate teaching inspired by Inquiry Based Science Education. Elmose and Sillasen discuss its value as a research model for qualitative evaluation of teaching and learning, and as a tool for formative evaluation in practical teaching and its ability to analyse relations between inquiry based teaching and competence learning.

Veera Kallunki's article is entitled "Active and spontaneous learning in a small group - a case of learning DC-circuit phenomena in the 3rd grade". The focus is on the progressive nature of learning sciences, and especially on its active and spontaneous components. The author examines learning in a small group from the standpoint of pupil's talk. Kallunki shows that even in the case of abstract subject matter, a small group can be a fruitful learning environment, where active and spontaneous learning can take place. 
Anna Danielsson has a contribution called "Science for whom? Case studies of two male primary school student teachers' constructions of themselves as teachers of science”. Her project investigates the intersections of gender and the teaching and learning of science. The paper explores the two student teachers' classed and gendered interpretations of school science, in particular how they use these interpretations as a means for them as male teachers to fit into the primary teacher role with its feminine connotations.

Lars Domino Østergaard has written a text entitled "Multimodal evaluering af deltagerstyret problem- og undersøgelsesbaseret aktiviteter i børnehave og indskoling." He has designed a multimodal assessment method with three central representations in focus of assessment: Written, oral and practical representations. The method is tried out in both kindergarten and in primary school, which have worked with inquiry based science education (IBSE) related to the subject "Wind \& Weather". The results indicate that the method gives the evaluator opportunities to test students' knowledge, skills and competencies related to science as well as students' social and personal competencies.

Hanne Mehli's article has the title "Blant ordentlige fysikere - Hvilken betydning har en fysikkcamp i et autentisk forskningsmiljø for fysikkelever i videregående skole?” This article reports from a qualitative study of physics students in upper secondary school participating in a camp at the Andøya Rocket Range in Northern Norway. The students worked together with students from other schools, engineers and physicists for three days. Mehli discusses how this kind of experience may contribute to the development of more physics-related identities among students in upper secondary school, and how this in turn may influence the students' further career choices.

Helena Sagar and Hanne Mehli write about "Authentic and entrepreneurial teaching practice in science and technology - variation and diversity in outcomes from professional development courses for teachers". They have used the same analytical tool to analyse the teachers' self-expressed outcomes from two different continuous professional development (CPD) courses. Both courses have impact on practice, but with different outcome-types of the two CPD approaches. Their paper illustrates the complexity involved in CPD evaluations and they discuss what needs to addressed in evaluations.

Annika Manni and colleagues' article is entitled "Perceived learning experiences regarding Education for sustainable development- within Swedish outdoor education traditions”. Their article presents results from an exploratory study investigating perceptions of the learning experiences related to education for sustainable development (ESD) by students 10-12 years old. The empirical material consists of responses from 209 students from six schools. The results reported reveal relationships between areas of students' learning experiences, mainly between the cognitive, emotional, and social areas. Comparisons between the schools illustrate different approaches to teaching as well as the students' diverse perceptions of these practices.

We strongly encourage submissions to NorDiNa's curriculum development section. In this issue, Sonja Mork gives an overview of the revised science curricula in Norway with an increased focus on generic skills such as reading and writing texts in the science subjects. Claas Wegner, Sven Grügelsiepe and Stephanie Ohlberger give an overview of the Kolumbus-youth project in Germany.

The Nordic Research Symposium on Science Education (NFSUN) will be held in Helsinki 4th-6th of June 2014. In this issue, you will find information about this event. A special issue of NorDiNa with contributions from the NFSUN is planned.

We wish you to enjoy your reading!

Carl-Johan Rundgren, Are Turmo, Christina Ottander \& Svein Sjøberg 